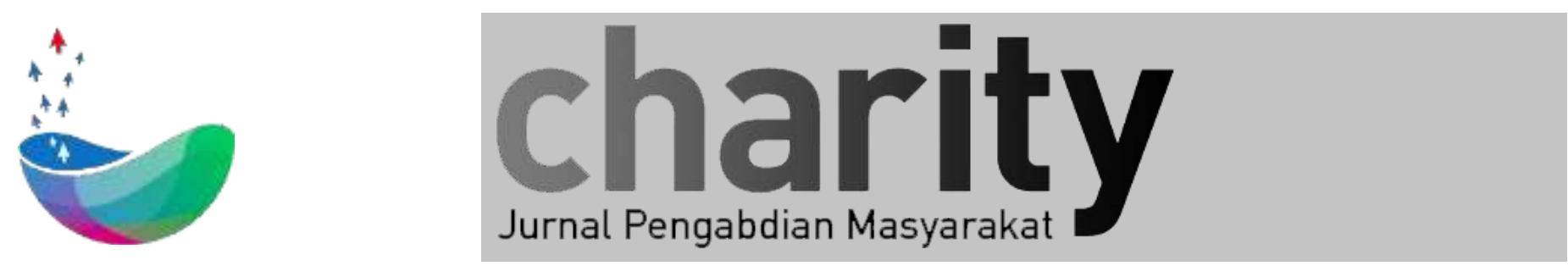

\title{
IMPLEMENTASI MEDIA BRANDING BAGI SENTRA UKM REST AREA PASIR JAMBU
}

\author{
Bijaksana Prabawa ${ }^{1}$, Rizki Yantami Arumsari ${ }^{2}$, Wirania Swasty ${ }^{3}$, Aldi Hendrawan ${ }^{4}$, Citra Puspita Sari ${ }^{5}$ \\ ${ }^{1,2,3}$ Desain Komunikasi Visual, Fakultas Industri Kreatif, Universitas Telkom \\ ${ }^{4,5}$ Kriya Tekstil dan Mode, Fakultas Industri Kreatif, Universitas Telkom \\ Dept. Dari penulis ke3, Fakultas, Instistusi \\ ${ }^{4}$ Dept. Dari penulis ke4, Fakultas, Instistusi \\ ${ }^{5}$ Dept. Dari penulis ke5, Fakultas, Instistusi \\ * email_dari_penulis ke-1, email_dari_penulis ke-2, email_dari_penulis ke-3, email_dari_penulis ke-4, email_dari_penulis ke-5
}

\section{INFO ARTIKEL}

Diterima 16 Agustus 2019

Direvisi 23 Agustus 2019

Disetujui 30 Agustus 2019

Tersedia Online 6 Juli 2020

\begin{abstract}
ABSTRAK
Sentra UKM Rest Area Pasirjambu merupakan sekelompok UKM yang bergabung dalam sebuah sentra di wilayah Rest Area Pasirjambu, tepatnya berlokasi di Jl. Raya Pasir Jambu KM 10, Ciwidey, Bandung. Sentra UKM Rest Area Pasirjambu terhitung masih baru didirikan, yaitu pada pertengahan 2017. Kondisi ini menyebabkan brand awareness dari masyarakat sekitar dan pengunjung rest area pasirjambu masih rendah. Tentu saja hal ini membutuhkan strategi bisnis tertentu salah satunya adalah dengan melakukan penguatan Brand. Oleh Karena itu, pada pengabdian masyarakat kolaborasi internal ini akan dilakukan formulasi strategi Branding melalui implementasi pada berbagai media Informasi dan komunikasi seperti media interaktif (website dan social media), media identitas perusahaan (logo, stationary, sign system, seragam, dsb), dan media persuasi/ promosi. Dengan penerapan media informasi dan komunikasi yang terintegrasi diharapkan tujuan dalam meningkatkan tingkat kunjungan sekaligus penguatan brand Sentra UKM ini dapat terwujud.
\end{abstract}

Keyword: branding, UKM, rest area, Pasir Jambu

Korespondensi:

Direktorat Penelitian dan Pengabdian Masyarakat, Universitas Telkom

Jl. Telekomunikasi No. 1, Terusan Buah Batu, Bandung, 40257

Indonesia

E-mail : charity@telkomuniversity.ac.id

ORCID ID: -

Penulis Pertama: Bijaksana Prabawa

https://doi.org/10.25124/charity.v2i2.2185

Paper_reg_number 2185 @ The Authors. Published by Directorate of Research and Community Service, Telkom University.

This is an open access article under the CC BY-NC 4.0 license (https://creativecommons.org/licenses/by-nc/4.0) 


\section{PENDAHULUAN}

UKM telah memberikan kontribusi yang besar dalam menyediakan lapangan pekerjaan dan pendapatan bagi masyarakat Indonesia. Karena itu, pemberdayaan dan pengembangan yang berkelanjutan perlu dilakukan agar UKM tidak hanya tumbuh dari aspek jumlah semata, tetapi juga dalam aspek kualitas dan daya saing produk beserta brandnya.

Branding merupakan suatu proses yang digunakan untuk membangun kesadaran dan memperluas loyalitas pelanggan. Peran branding sangat penting bagi para pelaku usaha baik usaha skala besar maupun usaha kecil menengah. Dengan melakukan branding berarti pelaku usaha tersebut mengekspresikan mengapa orang harus menerima dan memilih produk dari merek tersebut. Kegiatan pengabdian masyarakat Universitas Telkom dimaksudkan untuk membantu memecahkan permasalahan strategis secara global salah satunya persaingan dan tuntutan ekonomi baik lokal, nasional, maupun global/ internasional. Kegiatan ini diarahkan untuk berkontribusi dalam membentuk, mengelola, dan mendampingi masyarakat mandiri sebagai masyarakat binaan yang dapat berkontribusi secara ekonomi baik untuk wilsayahnya sendiri, nasional, maupun global sesuai dengan tuntutan perkembangan teknologi dan zaman.

Dinas Koperasi UKM Kabupaten Bandung merupakan mitra yang kami ajak untuk melakukan kegiatan pengabdian masyarakat, yang beralamat di Jalan Raya Soreang KM 17. Dinas Koperasi tersebut memiliki banyak program dan masyarakat binaan yang akan menjadi masyarakat sasar kegiatan pengabdian masyarakat ini. Adapun masyarakat sasar pada kegiatan pengabdian masyarakat ini adalah Sentra UKM Rest Area Pasirjambu, sebagai salah satu program binaan dari Dinas Koperasi dan UKM Kabupaten Bandung.

Sentra UKM Rest Area Pasirjambu merupakan sekelompok UKM yang bergabung dalam sebuah sentra di wilayah Rest Area Pasirjambu, tepatnya berlokasi di Jl. Raya Pasir Jambu KM 10, Ciwidey, Bandung. UKM yang tergabung sebagian besar merupakan pengusaha kuliner/camilan khas Kabupaten Bandung seperti sate cilampeni, gulai dan pindang. Sentra UKM ini juga merupakan hasil kerja sama bersama Himpunan Pengolah Hasil Pertanian (PPHP) Kab. Bandung.

Sentra UKM Rest Area Pasirjambu terhitung masih baru didirikan, yaitu pada pertengahan 2017. Kondisi ini menyebabkan brand awareness dari masyarakat sekitar dan pengunjung jalan Tol pasirjambu masih rendah. Pihak pengelola menginginkan sentra UKM ini bukan sekedar tempat dimana para pengunjung hanya datang untuk beristirahat semata, tetapi memiliki cita-cita menjadi salah satu destinasi wisata kuliner di wilayah Ciwidey. Tentu saja hal ini membutuhkan strategi bisnis tertentu salah satunya adalah dengan melakukan penguatan Brand. 
Oleh Karena itu, pada pengabdian msyarakat kolaborasi internal ini akan dilakukan formulasi strategi Branding melalui implementasi pada berbagai media Informasi dan komunikasi seperti media interaktif (website dan social media), media identitas perusahaan (logo, stationery, sign system, seragam, dsb), dan media persuasi/ promosi. Dengan penerapan media informasi dan komunikasi yang terintegrasi maka diharapkan tujuan dari pihak pengelola dalam meningkatkan tingkat kunjungan sekaligus penguatan brand Sentra UKM ini dapat terwujud.

\section{PERMASALAHAN}

Seiring dengan semakin meningkatnya kompetisi, maka pelaku UKM harus sangat memperhatikan masalah branding. Branding merupakan proses yang digunakan untuk membangun kesadaran dan loyalitas pelanggan yang perannya sangat penting untuk pelanggan memutuskan akan menggunakan dan loyal pada sebuah produk.

Permasalahan yang dihadapai pada masyarakat sasar adalah masih rendahnya Brand Awareness pengunjung terhadap sentra UKM rest area Pasir Jambu. Lebih jauh lagi, adanya keinginan pengelola untuk menjadikan sentra ini sebagai salah satu destinasi wisata kuliner diwilayah Ciwidey. Berdasarkan data yang diperoleh, maka disimpulkan permasalahan tersebut terkait dengan belum adanya strategi branding berikut implementasinya pada media-media informasi dan komunikasi. Adapun hal tersebut dapat di jelaskan lebih lanjut sebagai berikut:

1. Belum adanya identitas sentra sebagai karakter yang dapat membantu dalam meningkatkan Brand Awareness

2. Belum adanya media sign sebagai strategi menginformasikan keberadaaan sekaligus mengarahkan pengunjung menuju lokasi Sentra

3. Belum adanya media berbasis digital sebagai sarana interaksi bagi pengunjung loyal maupun pengunjung potensial

4. Belum adanya media persuasi dalam bentuk konten promosi yang dapat membujuk pengunjung untuk datang sekaligus melakukan transaksi.

Berangkat dari hal diatas maka pengabdian masyarakat kolaborasi internal ini akan melakukan implementasi strategi branding yang terintegrasi secara menyeluruh melalui perancangan sekaligus hibah media-media informasi dan komunikasi. 


\section{METODE PELAKSANAAN}

\subsection{Metode Pelaksanaan}

Kegiatan pengabdian masyarakat dilakukan melalui aktivitas survei lapangan dan wawancara. Survei lapangan dilakukan dengan melakukan kunjungan atau pengamatan langsung ke Dinas Koperasi dan UKM kabupaten Bandung dan Sentra UKM Rest Area Pasirjambu. Hasil dari survey lapangan berupa sistem pengelolaan, permasalahan, dan kebutuhan pada masyarakat sasar. Wawancara dilakukan kepada perwakilan mitra Kepala Seksi UKM Kabupaten Bandung dan kepala pengelola sentra sebagai masyarakat sasar.

\subsection{Teknik Pengumpulan Data}

Teknik pengambilan data berupa pernyataan kuesioner, wawancara dan observasi. Wawancara dilakukan kepada pihak masyarakat sasar dalam hal ini adalah manajemen Rest Area Pasir Jambu beserta pemangku kepentingan terkait. Observasi dilakukan dengan melakukan pengamatan langsung terhadap seluruh output visual yang telah ada.

\subsection{Teknik Analisis Data}

Teknik analisis data kuesioner yang dilakukan adalah deskriptif kuantitatif, bertujuan untuk mendapatkan gambaran karakteristik rest area. Adapun untuk hasil wawancara dilakukan analisis menggunakan metoden content analysis baik terhadap data tulisan maupun visual

\subsection{Lokasi, Waktu, dan Durasi Kegiatan}

Kegiatan pengabdian masyarakat ini dilaksanakan di Rest Area Pasir Jambu, Ciwidey, Bandung dari bulan Mei hingga Juli 2019.

\section{ANALISA HASIL KEGIATAN}

Kegiatan yang dilakukan dalam pengabdian masyarakat ini adalah berupa perancangan brand identity dan brand communication pada Rest Area Pasir Jambu. Kegiatan ini terbagi menjadi 3 tahap, yaitu tahap pengumpulan data, tahap perancangan, dan tahap pengawasan.

a. Tahap pengumpulan data didapatkan hasil sebagai berikut:

- Hasil kuesioner mengindikasikan perlunya program pengabdian masyarakat terkait keterbatasan finansial, kompetensi (pemahaman) dan kapabilitas masyarakat sasar

- Hasil dari wawancara mengindikasikan masih belum adanya brand identity serta sistem desain yang kuat. Hal ini berpengaruh pada masih rendahnya citra yang ditampilkan oleh Rest area Pasir Jambu. Temuan selanjutnya adalah masih belum jelasnya target konsumen dari masyarakat sasar yang mengakibatkan masih rendahnya brand awareness.

- Berdasarkan hasil observasi, Rest Area Pasir Jambu sendiri sudah melakukan beberapa aktivasi brand, walaupun secara implementasi secara visual belum efektif, terutama terkait lemahnya identitas brand dan sistem desain. 
b. Tahap perancangan menghasilkan media-media sebagai berikut:

a. Media identitas berupa logo

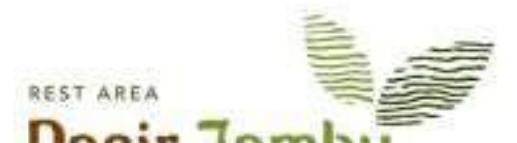

\section{Pasir Jambu}

Gambar 1 Redesign Logo Rest Area Pasir Jambu

b. Media stationery berupa kartu nama, amplop dan kertas surat
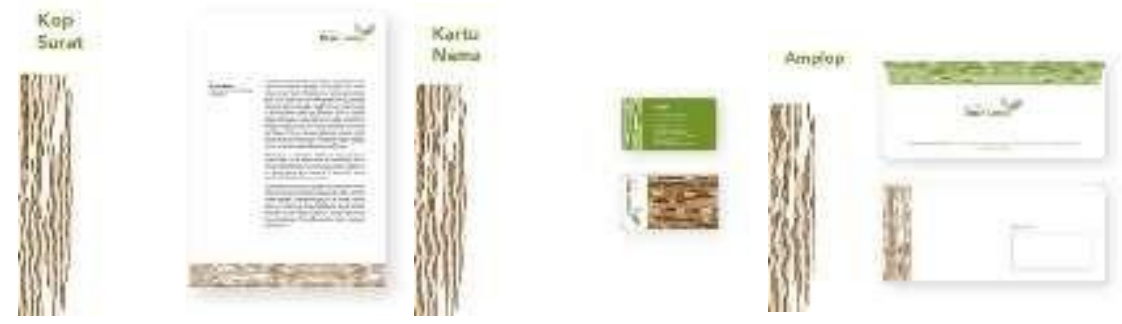

Gambar 2 Hasil Perancangan Stationery Rest Area Pasir Jambu

c. Media identification sign bagi fasilitas yang tersedia
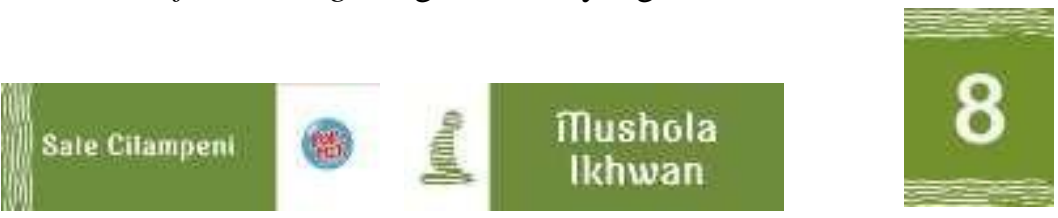

Gambar 3 Hasil Perancangan Identification Sign Rest Area Pasir Jambu

d. Media Seragam untuk Front Office dan Back Office
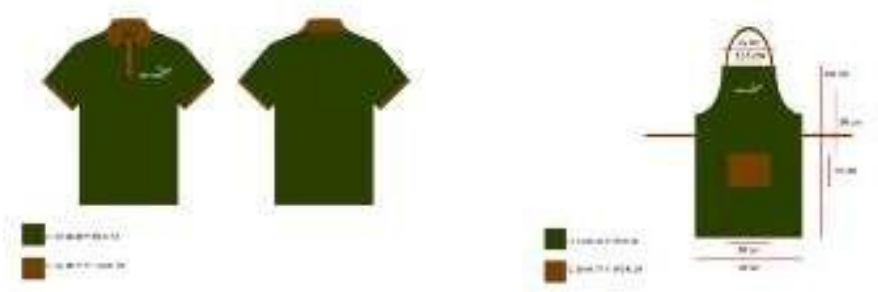

Gambar 4 Hasil Perancangan Seragam dan Apron Area Pasir Jambu

c. Tahap pengawasan dilakukan setelah media-media perancangan diserahkan.

Pada tahap ini pengawasan dan konsultasi masih berjalan hingga 6 bulan setelah kegiatan berjalan, sehingga efektifitas dari program ini terjaga dan media yang dirancangan menjadi aplikatif. 


\section{KESIMPULAN DAN SARAN}

5.1 Kesimpulan

Kegiatan pengabdian kepada masyarakat ini bermanfaat bagi Rest Area Pasir Jambu dalam membentuk brand image dan meningkatkan brand awareness konsumen.

\subsection{Saran}

Diharapkan kegiatan pengabdian kepada masyarakat ini dapat terus dilakukan dan secara kolaborasi agar output pemecahan masalahnya dapat lebih beragam.

\section{DAFTAR PUSTAKA}

Fikri, Chairul. 2017. Peran Branding Dinilai Semaking Penting.

http://www.beritasatu.com/ekonomi/434141-peran-branding-dinilai-semakingpenting.html\%20/. Kamis, 1 Juni 2017 [Terakhir diakses pada 13 Maret 2018]

Swasty, Wirania. 2016. Branding: Memahami dan Merancang Strategi Merek. Bandung: PT. Remaja Rosdakarya. 